\title{
Design and Economic Analysis of a Stand-Alone PV System to Electrify a Remote Area Household in Egypt
}

\author{
Abd El-Shafy A. Nafeh* \\ Electronics Research Institute, Cairo, Egypt
}

\begin{abstract}
This paper presents a study on a stand-alone photovoltaic (PV) system to provide the required electricity for a single residential household in Sinai Peninsula of Egypt. The complete design of the suggested system is carried out, such that the site radiation data and the electrical load data of a typical household in the considered site are taken into account during the design steps. Also, the life cycle cost (LCC) analysis is conducted to assess the economic viability of the system. The results of the study encouraged the use of the PV systems to electrify the remote sites of Egypt.
\end{abstract}

Keywords: Remote area electrification, PV array, storage battery, battery charge controller, inverter.

\section{INTRODUCTION}

Photovoltaic (PV) energy production is recognized as an important part of the future energy generation mix [1]. Because it is non-polluting, free in its availability, and is of high reliability. Therefore, these facts make the PV energy resource attractive for many applications, especially in rural and remote areas of most of the developing countries [2]. small communities and settlements that are too far from the power grid and consequently will not be connected to it [4].

Sinai Peninsula is characterized by its high mountains and decentralized communities that are far from the power grid of Egypt. Most of those communities are still unelectrified. Where, the houses of those communities are characterized by poor inhabitants, low power demand, fixed load, and

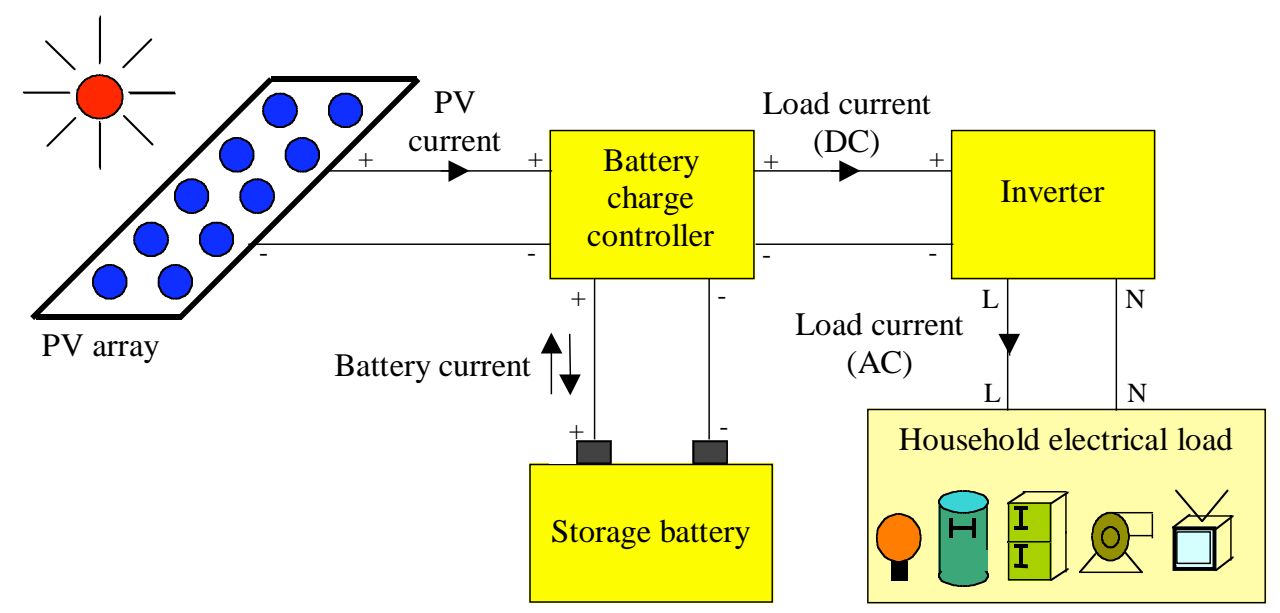

Fig. (1). The stand-alone PV system.

Egypt is located in the world's solar belt and has an excellent solar availability. The annual average total solar radiation over Egypt ranges from about $1950 \mathrm{kWh} / \mathrm{m}^{2} / \mathrm{year}$ on the Mediterranean coast to more than $2600 \mathrm{kWh} / \mathrm{m}^{2} /$ year in Upper Egypt. About $90 \%$ of the Egyptian territory have an average total radiation greater than $2200 \mathrm{kWh} / \mathrm{m}^{2} /$ year $[3,4]$. Egypt has got an ambitious plan for village electrification. More than $98 \%$ of the villages were electrified through the utility grid. However, there are still some remote isolated

*Address correspondence to this author at the Electronics Research Institute, Cairo, Egypt; E-mails: abdelshafyn @eri.sci.eg, abdelshafyn@yahoo.com dispersed nature. They are beyond the economic boundary of the utility and are therefore not included in the future plan for electrification from the national grid $[4,5]$.

This paper presents a study on the design and economical analysis of a stand-alone PV system to provide the required electrical energy for a single residential household in Egypt. The Egyptian location selected, as the site for the study, is near Abu Rudies city of Sinai Peninsula.

\section{THE HOUSEHOLD PV SYSTEM CONFIGURA- TION}

Fig. (1) shows the suggested block diagram of the household stand-alone PV system. Where, the function of the PV array is to convert the sunlight directly into DC electrical 


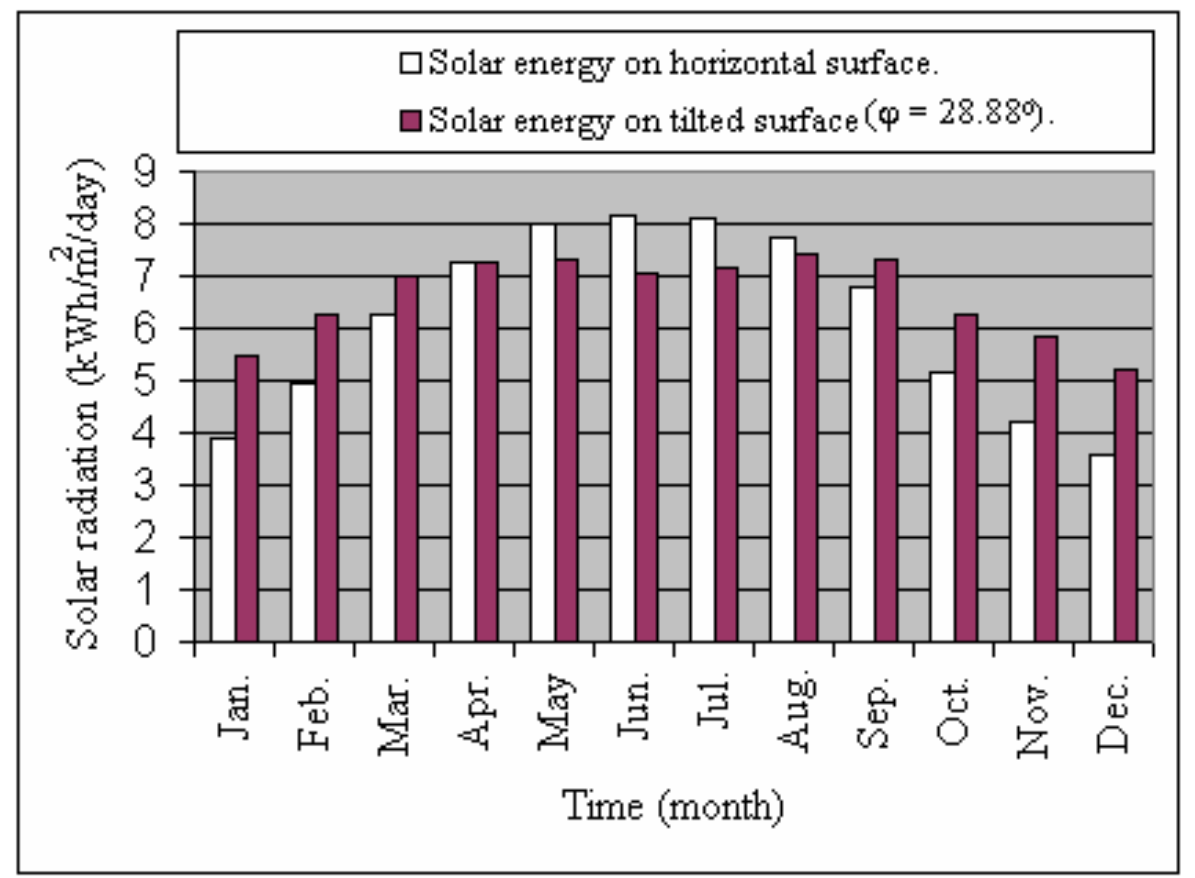

Fig. (2). The solar radiation data of the site.

Table 1. The Household Load Data

\begin{tabular}{|c|c|c|c|}
\hline Electrical Load & No. of Units & Operating Hours Per Day & Wattage Per Unit Used \\
\hline \hline Lighting lamp & 5 & from 11 to 13 & 60 \\
Washing machine & 1 & from 0 to 24 & 100 \\
Refrigerator & 1 & from 12 to 14 & 120 \\
Water pump & 1 & from 17 to 24 & 80 \\
TV & 1 & & \\
\hline
\end{tabular}

power and that of the battery is to store the excess power through using the battery charger. The inverter is used to convert the DC electrical power into AC power; to match the requirements of the common household AC appliances.

\section{SITE METEOROLOGICAL DATA}

To predict the performance of a PV system in a site, it is necessary to collect the meteorological or environmental data for the site location under consideration. The Egyptian Solar Radiation Atlas [3] is a good source for these data. The monthly average daily solar radiation data incident on both horizontal and south facing PV array tilted by the latitude angle $\varphi$ of the site is shown in Fig. (2). It is clear from the figure that solar energy incident in the considered site is very high especially during the summer months, where it exceeds 8 and $7 \mathrm{kWh} / \mathrm{m}^{2} /$ day on horizontal and tilted plans, respectively.

\section{ENERGY REQUIREMENT IN A HOUSEHOLD}

The remote area household in Egypt is simple and does not require large quantities of electrical energy used for lighting and electrical appliances. The electrical load data in a residential house are given in Table $\mathbf{1}$. The corresponding load profile for a typical day is indicated in Fig. (3).

\section{PV SYSTEM DESIGN}

To design a stand-alone PV system for the considered household, the following steps are required.

\subsection{The Average Daily Solar Energy Input}

Fig. (2) can be used to calculate the average daily solar energy input over the year $\left(\mathrm{G}_{\mathrm{av}}\right)$ on a south facing surface tilted at an angle equal to the site latitude $\varphi$ to be about 6.62 $\mathrm{kWh} / \mathrm{m}^{2} /$ day. It is to be noted that the above result is also available directly in [3]. 


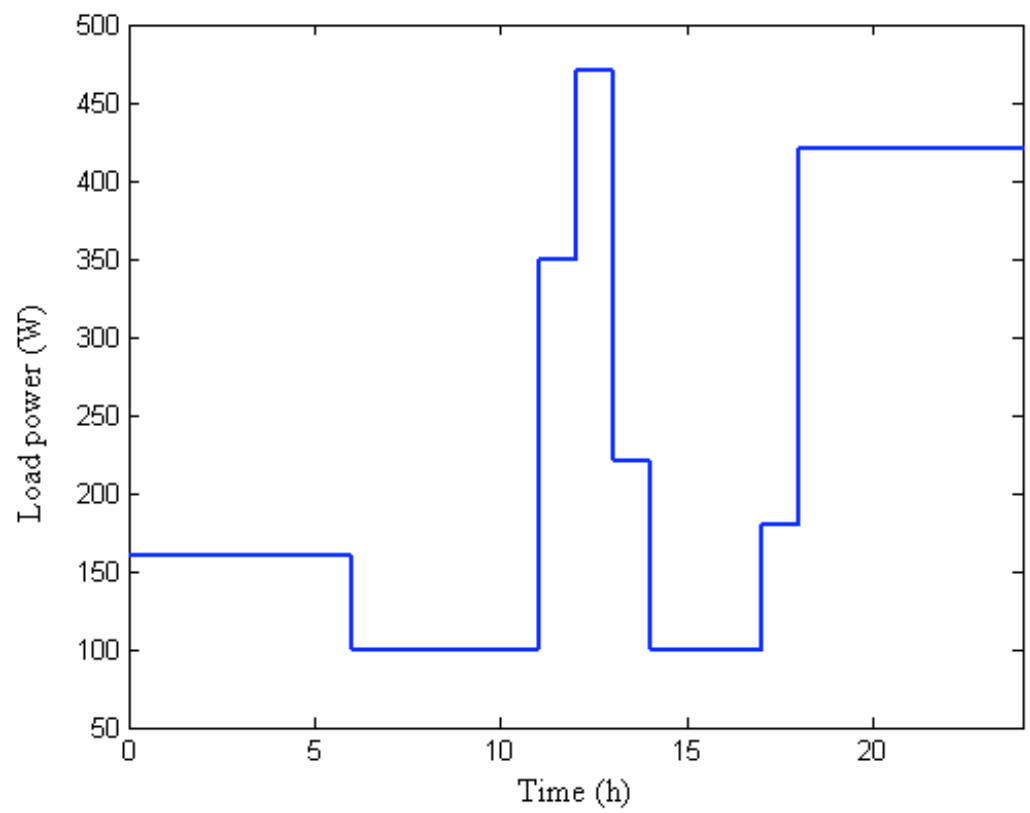

Fig. (3). The load profile of the household.

\subsection{The Average Daily Load Demand}

The average daily load demand $\mathrm{E}_{\mathrm{L}}$ can be calculated from Fig. (3), to be $5500 \mathrm{Wh} /$ day.

\subsection{Sizing of the PV Array}

The size of the PV array, used in this study, can be calculated by the following equation [6]:

$$
P V \text { area }=\frac{E_{L}}{G_{a v} \times \eta_{P V} \times T C F \times \eta_{\text {out }}}
$$

Where,

$\begin{array}{ll}\mathrm{G}_{\mathrm{av}} & \text { average solar energy input per day } \\ \text { TCF } & \text { temperature correction factor } \\ \eta_{\mathrm{PV}} & \text { PV efficiency } \\ \eta_{\text {out }} & \text { battery efficiency }\left(\eta_{\mathrm{B}}\right) \times \text { inverter efficiency } \\ & \left(\eta_{\text {Inv }}\right)\end{array}$

If the cell temperature is assumed to reach $60{ }^{\circ} \mathrm{C}$ in the field, then the temperature correction factor (TCF) will be 0.8 as indicated in [6]. Assuming $\eta_{\mathrm{PV}}=12 \%$ and $\eta_{\mathrm{out}}=0.85$ $\times 0.9=0.765$. Thus, using Eq. (1) the PV area is $11.3 \mathrm{~m}^{2}$.

The PV peak power, at peak solar insolation (PSI) of $1000 \mathrm{~W} / \mathrm{m}^{2}$, is thus given by [6,7]:

$$
P V \text { Peak power }=P V \text { area } \times P S I \times \eta_{P V}=1356 W_{P}
$$

The selected modules are mono-crystalline silicon, with the following specifications at standard test conditions (i.e., $1000 \mathrm{~W} / \mathrm{m}^{2}$ and $25^{\circ} \mathrm{C}$ ):

- Peak power: $23.2 \mathrm{~W}_{\mathrm{P}}$

- Peak-power voltage: $9.6 \mathrm{~V}$

- Peak-power current: 2.4167 A
Thus, 60 modules are used to supply the required energy for the residential house. The series and parallel configuration of the resulted PV array can be adjusted according to the required DC bus voltage and current, respectively. If the DC bus voltage is chosen to be $24 \mathrm{~V}$, then 3 modules will be connected in series and 20 strings (each of 3 modules in series) will be connected in parallel.

\subsection{Sizing of the Battery}

The storage capacity of the battery can be calculated according to the following relation $[7,8]$ :

$$
\text { Storage capacity }=\frac{N_{C} E_{L}}{D O D \cdot \eta_{\text {out }}}
$$

Where,

$\mathrm{N}_{\mathrm{C}} \quad$ largest number of continuous cloudy days of the site

DOD maximum permissible depth of discharge of the battery

The largest number of continuous cloudy days $\mathrm{N}_{\mathrm{C}}$ in the selected site is about 4 days. Thus, for a maximum depth of discharge for the battery DOD of 0.8 , the storage capacity becomes 35948 Wh (Eq. (3)). Since, the selected DC bus voltage is $24 \mathrm{~V}$, then the required ampere-hours of the battery $=35948 / 24 \approx 1500$ Ah. If a single battery (Vision 6FM250D) of $12 \mathrm{~V}$ and $250 \mathrm{Ah}$ is used, then 2 batteries are connected in series and 3 strings of batteries are connected in parallel; to give an overall number of 6 batteries.

\subsection{Design of the Battery Charge Controller}

The battery charge controller is required to safely charge the batteries and to maintain longer lifetime for them. It has to be capable of carrying the short circuit current of the PV array. Thus, in this case, it can be chosen to handle $50 \mathrm{~A}$ (i.e., $2.5 \mathrm{~A} \times 20$ ) and to maintain the $\mathrm{DC}$ bus voltage to about $24 \mathrm{~V}$. 
Table 2. The Used Cost Data of All Items

\begin{tabular}{|c|c|c|c|c|c|c|}
\hline Item & PV & Battery & Charger & Inverter & Installation & M\&O/Year \\
\hline \hline Cost & $\$ 5 / \mathrm{W}_{\mathrm{P}}$ & $\$ 1.705 / \mathrm{Ah}$ & $\$ 5.878 / \mathrm{A}$ & $\$ 0.831 / \mathrm{W}$ & $10 \%$ of PV cost & $2 \%$ of $\mathrm{PV} \cos t$ \\
\hline
\end{tabular}

\subsection{Design of the Inverter}

The used inverter must be able to handle the maximum expected power of AC loads. Therefore, it can be selected as $20 \%$ higher than the rated power of the total AC loads that presented in Table 1. Thus the rated power of the inverter becomes $1020 \mathrm{~W}$. The specifications of the required inverter will be $1020 \mathrm{~W}, 24 \mathrm{~V}_{\mathrm{DC}}, 220 \mathrm{~V}_{\mathrm{AC}}$, and $50 \mathrm{~Hz}$.

\section{LIFE CYCLE COST ANALYSIS}

In this section the life cycle cost (LCC) estimation of the designed stand-alone PV system is discussed. The LCC of an item consists of the total costs of owning and operating an item over its lifetime, expressed in today's money [9-13].

The costs of a stand-alone PV system include acquisition costs, operating costs, maintenance costs, and replacement costs. All these costs have the following specifications [9]:

- The initial cost of the system (the capital cost) is high.

- There are no fuel costs.

- Maintenance costs are low.

- Replacement costs are low (mainly for batteries).

The LCC of the PV system includes the sum of all the present worths (PWs) of the costs of the PV modules, storage batteries, battery charger, inverter, the cost of the installation, and the maintenance and operation cost $(\mathrm{M} \& \mathrm{O})$ of the system. The details of the used cost data for all items are shown in Table 2 [6, 11-13].

The lifetime $\mathrm{N}$ of all the items is considered to be 20 years, except that of the battery which is considered to be 5 years. Thus, an extra 3 groups of batteries (each of 6 batteries) have to be purchased, after 5 years, 10 years, and 15 years, assuming an inflation rate $\mathrm{i}$ of $3 \%$ and a discount or interest rate $d$ of $10 \%$. Therefore, the PWs of all the items can be calculated as follows $[9,10]$ :

- $\quad \mathrm{PV}$ array cost $\mathrm{C}_{\mathrm{PV}}=5 \times 60 \times 23.2=\$ 6960$

- Initial cost of batteries $C_{B}=1.705 \times 1500=\$ 2557.5$

- The PW of the $1^{\text {st }}$ extra group of batteries (purchased after $\mathrm{N}=5$ years) $\mathrm{C}_{\mathrm{B} 1 \mathrm{PW}}$ can be calculated, to be $\$ 1840.93$, from:

$$
C_{B 1 P W}=C_{B}\left(\frac{1+i}{1+d}\right)^{N}
$$

- The PW of the $2^{\text {nd }}$ extra group of batteries (purchased after $\mathrm{N}=10$ years) $\mathrm{C}_{\mathrm{B} 2 \mathrm{PW}}$ and that of the $3^{\text {rd }}$ extra group (purchased after $\mathrm{N}=15$ years) $\mathrm{C}_{\mathrm{B} 3 \mathrm{PW}}$ are calculated, using Eq. (4), to be $\$ 1325.14 \& \$ 953.86$, respectively.

- $\quad$ Charger cost $\mathrm{C}_{\mathrm{C}}=5.878 \times 50=\$ 293.9$

- Inverter cost $\mathrm{C}_{\text {Inv }}=0.831 \times 1020=\$ 847.62$
- Installation cost $C_{\text {Inst }}=0.1 \times 6960=\$ 696$

- The PW of the maintenance cost $\mathrm{C}_{\mathrm{MPW}}$ can be calculated to be $\$ 1498.35$, using the maintenance cost per year $(\mathrm{M} / \mathrm{yr})$ and the lifetime of the system $(\mathrm{N}=20$ years $)$, from [10]:

$$
C_{M P W}=(M / y r) *\left(\frac{1+i}{1+d}\right) *\left[\frac{1-\left(\frac{1+i}{1+d}\right)^{N}}{1-\left(\frac{1+i}{1+d}\right)}\right]
$$

Therefore, the LCC of the system can be calculated, to be \$16973.3, from:

$\mathrm{LCC}=\mathrm{C}_{\mathrm{PV}}+\mathrm{C}_{\mathrm{B}}+\mathrm{C}_{\mathrm{B} 1 \mathrm{PW}}+\mathrm{C}_{\mathrm{B} 2 \mathrm{PW}}+\mathrm{C}_{\mathrm{B} 3 \mathrm{PW}}$

$+\mathrm{C}_{\mathrm{C}}+\mathrm{C}_{\text {Inv }}+\mathrm{C}_{\text {Inst }}+\mathrm{C}_{\mathrm{MPW}}$

It is sometimes useful to calculate the LCC of a system on an annual basis. The annualized LCC (ALCC) of the PV system in terms of the present day dollars can be calculated, to be $\$ 1476.51 / \mathrm{yr}$, from $[9,10]$ :

$$
A L C C=L C C \frac{\left[1-\left(\frac{1+i}{1+d}\right)\right]}{\left[1-\left(\frac{1+i}{1+d}\right)^{N}\right]}
$$

Once the ALCC is known, the unit electrical cost (cost of $1 \mathrm{kWh}$ ) can be calculated, to be $\$ 0.74 / \mathrm{kWh}$, from:

$$
\text { Unit electrical } \cos t=\frac{A L C C}{365 E_{L}}
$$

Therefore, in remote sites that are too far from the Egyptian power grid, the PV installers are encouraged to sell the electricity of their PV systems at a price not lower than $\$ 0.74 / \mathrm{kWh}$ to earn a profit. It is to be noted, here, that although this price is very high compared to the current unit cost of electricity in Egypt $(\$ 0.1 / \mathrm{kWh}[14])$, this price will drop to $\$ 0.49 / \mathrm{kWh}$ if the future initial cost of the PV modules drops to $\$ 0.1 / \mathrm{W}_{\mathrm{P}}$. At the same time, if the future unit cost of electricity in Egypt becomes five times its current value, due to the rapid increase in the conventional fuel prices, therefore PV energy generation will be promising in the future household electrification (in Egypt) due to its expected future lower unit electricity cost, efficiency increase, and clean energy generation compared to the conventional utility grid.

\section{CONCLUSION}

Electrification of remote and isolated sites worldwide is very important especially in the developing countries as Egypt. The photovoltaic systems are considered as the most 
promising energy sources for these sites, due to their high reliability and safety. They represent, at the same time, a vital and economic alternative to the conventional energy generators. An electrification study for a single residential household in a remote isolated site of Sinai Peninsula is carried out using a stand-alone PV system. This study presents the complete design and the life cycle cost analysis of the PV system. The results of the study indicate that electrifying a remote isolated household using PV systems is beneficial and suitable for long-term investments, especially if the initial prices of the PV systems are decreased and their efficiencies are increased.

\section{REFERENCES}

[1] Ramachandrn, J.; Pearsall, N.M.; Putrus, G.A. In Reduction in Solar Radiation Fluctuation by Spatial Smoothing Effect, Proceedings of the $19^{\text {th }}$ European Photovoltaic Solar Energy Conference, Paris, France, June 2004, Vol. III, pp. 2900-2903.

[2] Ishengoma, F.M.; Norum, L.E. In Design and Implementation of a Digitally Controlled Stand-Alone Photovoltaic Power Supply, Proceedings of the Nordic Workshop on Power and Industrial Electronics (NORPIE/2002), Stockholm, Sweden, 2002, pp. 1-5.

[3] New and Renewable Energy Authority. Egyptian Solar Radiation Atlas, Ministry of Electricity and Energy, Cairo, Egypt, 1998.

[4] Vankeleom, J.; Dufourd, F.; Saleh, L.A. In ELVIRA: A Software for Rural Electrification in Developing Countries - Application for the Use of Photovoltaic Energy in Egypt, Proceedings of the $19^{\text {th }}$ European Photovoltaic Solar Energy Conference, Paris, France, June 2004, Vol. III, pp. 3452-3455.
[5] Taylor, R.; Abulfotuh, F. Photovoltaic Electricity in Egypt, Project Brief. http://www.rsvp.nrel.gov (accessed 2005).

[6] Alamsyah, T.M.I.; Sopian, K.; Shahrir, A. In Technoeconomics Analysis of a Photovoltaic System to Provide Electricity for a Household in Malaysia, Proceedings of the International Symposium on Renewable Energy: Environment Protection \& Energy Solution for Sustainable Development, Kuala Lumpur, Malaysia, 2003, pp. 387-396.

[7] Mahmoud, M.M.; Ibrik, I.H. Techno-economic feasibility of energy supply of remote villages in palestine by PV-systems, diesel generators and electric grid. Renewable Sustainable Energy Rev., 2006, 10, 128-138.

[8] Wenham, S.R.; Green, M.A.; Watt, M.E. Applied Photovoltaics, Center for Photovoltaic Devices and Systems: Australia, 1994.

[9] Markvart, T. Solar Electricity, John Wiley \& Sons: New York, 1994.

[10] Messenger, R.; Ventre, J. Photovoltaic Systems Engineering, CRC Press LLC: Boca Raton, Florida, USA, 2000.

[11] Celik, A.N. Effect of different load profiles on the loss-of-load probability of stand-alone photovoltaic systems. Renewable Energy, 2007, 32, 2096-2115.

[12] Ajan, C.W.; Ahmed, S.S.; Ahmed, H.B.; Taha, F.; Zin, A.A.B.M On the policy of photovoltaic and diesel generation mix for an offgrid site: East Malaysian Perspectives. Solar Energy, 2003, 74, 453-467.

[13] Celik, A.N. Present status of photovoltaic energy in turkey and life cycle techno-economic analysis of a grid-connected photovoltaichouse. Renewable Sustainable Energy Rev., 2006, 10, 370-387.

[14] Egyptian Electric Utility and Consumer Protection Regulatory Agency. Electric Energy Prices. http://www.egyptera.com/en/Bill_Tariffs.htm (accessed January 2009).

(c) Abd El-Shafy A. Nafeh; Licensee Bentham Open.

This is an open access article licensed under the terms of the Creative Commons Attribution Non-Commercial License (http://creativecommons.org/licenses/by-nc/3.0/) which permits unrestricted, non-commercial use, distribution and reproduction in any medium, provided the work is properly cited. 